\title{
Rowan Williams's Political Theology: Multiculturalism and Interactive Pluralism
}

\author{
Mark D. Chapman \\ MChapman@ripon-cuddesdon.ac.uk
}

\begin{abstract}
This essay discusses the political thought of Rowan Williams in the context of his leading influences and wider theology. It shows the continuity in his political writing from his early days as a radical to his frequent political speeches and lectures as Archbishop of Canterbury. The over-riding theme is that of 'interactive pluralism', which seeks to establish a form of politics with a very weak system of sovereignty. This influenced his 2008 lecture on 'Civil and Religious Law in England: a Religious Perspective', which suggested a limited role for parallel religious law codes alongside those of the state. Although this lecture was subject to much criticism, particularly in the popular press, it nevertheless displays a consistency with his strongly disestablishmentarian inclinations, which give a large amount of space to 'first-level' institutions in both decision-making and community formation. A healthy society is established through dispute and dialogue between such groups rather than strong centralized power.
\end{abstract}

KEYWORDS: Archbishop of Canterbury, Islam, J.N. Figgis, pluralism, political theory, tolerance

\section{The Background to Williams's Political Thought}

In 1984, Rowan Williams wrote an essay on 'Liberation Theology and the Anglican Tradition' where he discussed the impact of what was then a relatively new theological movement and how it might affect the Church of England. He delineates a number of obvious differences between English Anglicanism and the sort of political theology that had developed in Latin America. First, he notes the established nature of the Church of England and the 'assumption of absolute givenness in 
the political structure'. ${ }^{1}$ On this sort of model, which was obviously central to the origin of the Church of England in its break with Rome, and which was maintained in the nineteenth century by F.D. Maurice (among many others), the Church cannot govern 'precisely because it is not a body separable from the state'. ${ }^{2}$ For much of Anglican history, there was a harmonious and singular vision of church and state as one body. Within the Church of England significant critics of this understanding of church and state emerged in the late nineteenth and early twentieth centuries, many of whom, including Charles Gore and other Anglo-Catholics, clamoured for a 'free church in a free state'. ${ }^{3}$ This separatist movement obviously carried with it certain political implications.

According to Williams, the most important theorist in this development was the scholar-monk John Neville Figgis, who differentiated between two forms of political authority. Figgis was one of the socalled English Political Pluralists, who included among their number G.D.H. Cole and Harold Laski (although both later changed their minds), and who were active in the early years of the twentieth century. ${ }^{4}$ Although the Political Pluralists drew on the writings of earlier figures, most importantly the German legal historian, Otto von

1. Rowan Williams, 'Liberation Theology and the Anglican Tradition', in Rowan Williams and David Nicholls (eds.), Politics and Theological Identity: Two Anglican Essays (London: The Jubilee Group, 1984), pp. 7-26 (17).

2. Williams, 'Liberation Theology and the Anglican Tradition', p. 18.

3. On this, see Harold Laski's fascinating remarks about establishment (in Political Thought in England from Locke to Bentham (London: Williams and Norgate, 1920)): " "Thoughtful men", the Archbishop of Canterbury has told the House of Lords, "... see the absolute need, if a Church is to be strong and vigorous, for the Church, qua church, to be able to say what it can do as a church". "The rule of the sovereign, the rule of Parliament", replied Lord Haldane, "extend as far as the rule of the Church. They are not to be distinguished or differentiated, and that was the condition under which ecclesiastical power was transmitted to the Church of England". Today, that is to say, as in the past, antithetic theories of the nature of the State hinge, in essence, upon the problem of its sovereignty. "A free church in a free state", now, as then, may be our ideal; but we still seek the means wherewith to build it' (p. 85).

4. On political pluralism, see especially Gongquan Xiao, Political Pluralism: a Study in Contemporary Political Theory (London: K. Paul, Trench, Trubner, 1927); David Runciman, Pluralism and the Personality of the State (Cambridge: Cambridge University Press, 1987); Marc Stears, Progressives, Pluralists, and the Problems of the State; Cécile Laborde, Pluralist Thought and the State in Britain and France, 1900-25 (Basingstoke: Macmillan, 2000); and Paul Q. Hirst (ed.), The Pluralist Theory of the State (London: Routledge, 1989). 
Gierke, they developed an understanding of the state based on a very different model of sovereignty from that maintained by opponents such as John Austin. Figgis thus differentiated between two forms of authority. On the one hand, he described a form of absolutist sovereignty, which manifested itself in the idea that all forms of association - including the church - were granted by the sovereign's will. ${ }^{5}$ On the other hand, however, he also outlined a theory of association where the voluntary corporation rather than the sovereign state was understood as the primary political unit. Figgis's principal contribution to political theory was his application of the theory of associations to the organization and role of churches in his ground breaking Churches in the Modern State. ${ }^{6}$ On this model, Williams writes:

\begin{abstract}
State authority simply means that, in an association of such associations (an association essentially fluid and dependent upon a variety of factors such as language or geography), power is delegated to the unifying structure in order to balance the claims and order the relations of the smaller units. In this perspective rights can, in certain circumstances, be claimed against the state, because the sovereign state power is not their source. ${ }^{7}$
\end{abstract}

For Figgis, as for Williams, federalism and decentralization become the hallmarks of such a system of politics, political arrangements that were hinted at in the conciliar movements of the fourteenth and fifteenth centuries. ${ }^{8}$ Although the Reformation period saw a resurgence and to some extent a triumph of absolute sovereignty, particularly among rulers like Henry VIII, Francis I and Philip II, Williams suggests (again with Figgis) that the religiously monolithic state has completely broken down since the Enlightenment. This means that in the modern world churches, including the Church of England, have become voluntary organizations to which nobody can be compelled to belong. Consequently, Williams claims, the only 'ground upon which the Church of England can now justify its existence ... is a federalist theory of ecclesiastical unity and authority'. This carries with it implicit political implications, since, as Williams puts it, '[w]e cannot consistently be federalists in our ecclesiology and absolutists in our

5. On Figgis, see my Bishops, Saints and Politics: Anglican Studies (London: T \& T Clark, 2007), ch. 4, pp. 69-94.

6. J.N. Figgis, Churches in the Modern State (London: Longmans, 1914).

7. 'Liberation Theology and the Anglican Tradition', p. 21.

8. On Figgis and conciliarism, see my essay, 'The Dull Bits of History: Cautionary Tales for Anglicanism', in Mark D. Chapman (ed.), The Anglican Covenant: Unity and Diversity in the Anglican Communion (London: Mowbray, 2008), pp. 81-99. 
politics'. For this reason, he suggests provocatively: 'It might even be said that the Anglican Christian has a peculiarly direct reason for adopting a strongly syndicalist view of political power and of the rights of associations over against an encroaching state. ${ }^{9}$ And it need hardly be said that for an archbishop in an established church this is a very bold claim (although admittedly he said it a long time before he was elevated to Canterbury).

In such a system, the state's role is to work out a system of justice and to 'rectify imbalances'. The state thereby becomes an arbitrator, rather than as a commanding sovereign. While in the end it might have to exercise sovereign power, this is conferred on the state by the participating parties, rather than by nature. According to Williams, this means that Figgis turns the Anglican synthesis of church and state on its head. Gone are the old organic unity and pre-established harmonies of the sovereign state, and in their place emerges a political system that is more about negotiation and pluralism than about absolutism and sovereignty. Williams's 1984 essay provides a preliminary statement of a number of guiding themes that have shaped his approach to theology and political theory ever since, ${ }^{10}$ and which have re-emerged in his time as archbishop. However, perhaps not surprisingly - in 1984 there is no mention of Islam or other religions. ${ }^{11}$ In the intervening 20 years or so there has been a recognition by many church leaders of the importance of the need to understand and engage with the other faith communities present in the multi-faith society of contemporary Britain. Indeed, it would be fair to say that in his application of pluralist thought to modern society, Williams has been one of the first Christian leaders to move to a level of sophisticated theological thought about multiculturalism.

Despite the changes of the past 20 years, there is a strong sense of continuity in Williams's writings. He remains deeply inspired by Figgis and has developed this at length in many of his recent lectures on multi-faith society in modern Europe. Although he no longer uses the term 'syndicalism' - which is probably just as well given its association with anarchism - there is much in his theory of what he

9. Williams, 'Liberation Theology and the Anglican Tradition', p. 22.

10. See also 'The Trinity and Pluralism', in Rowan Williams (ed.), On Christian Theology (Oxford: Blackwell, 2000), pp. 167-80.

11. The rising influence of other religions was scarcely noted in the influential report of the Archbishop of Canterbury's Commission on Urban Priority Areas: Faith in the City: a Call for Action by Church and Nation (London: Church House Publishing, 1985). 
calls 'interactive pluralism' that owes its origin to the English pluralist tradition of the early twentieth century. For instance, in a lecture given to the European Institutions in 2005, Williams writes:

If the state has no sacred character, it is not the sole source of legitimate common life: intermediate institutions, guilds, unions, churches, ethnic groups, all sorts of civil associations, have a natural liberty to exist and organise themselves, and the state's role is to harmonise and to some degree regulate this social variety. This 'interactive pluralism', rooted in the liberalism of thinkers like Acton, Maitland and Figgis, would see the healthy state neither as a group of suspiciously coexisting groups, nor as a neutral legal unit whose citizens all possessed abstractly equal rights, but as a space in which distinctive styles and convictions could challenge each other and affect each other, but on the basis that they first had the freedom to be themselves. ${ }^{12}$

\section{Interactive Pluralism}

The clearest exposition of 'interactive pluralism' that Williams has offered so far during his time as archbishop is his David Nicholls Memorial Lecture. ${ }^{13}$ Williams used Nicholls's own discussions of Figgis and other pluralists including Nicholls himself ${ }^{14}$ to outline his own approach to the relationship between state and what he calls 'first-level' associations. ${ }^{15}$ Regarding Figgis and others as still offering a 'powerful analysis', ${ }^{16}$ he observes that the role of the state is principally that of brokerage, in order to provide

the stable climate for all first-level communities to flourish and the means for settling - and enforcing - 'boundary disputes' between them. The law does not attempt total regulation of how these communities govern themselves (though it may, as with British charity law, require certain standards of accountable practice). ${ }^{17}$

12. 'Religion, Culture, Diversity and Tolerance: Shaping the New Europe', November 8, 2005. Posted at: http://www.anglicancommunion.org/acns/ news.cfm/2005/11/8/ACNS4068

13. 'Law, Power and Peace: Christian Perspectives on Sovereignty', September 25, 2005. Posted at http://www.dnmt.org.uk/dnmt/images/docs/dnmlecture_2005.pdf

14. David Nicholls, The Pluralist State (London: Macmillan, 2nd edn, 1994) and 'Authority in Church and State aspects of the thought of J.N. Figgis and his contemporaries' (unpublished Cambridge PhD dissertation, 1962). See more generally, Marc Stears, Progressives, Pluralists, and the Problems of the State: Ideologies of Reform in the United States and Britain, 1909-1926 (Oxford: Oxford University Press, 2002).

15. 'Law, Power and Peace', p. 1.

16. 'Law, Power and Peace', p. 3.

17. 'Law, Power and Peace', p. 2. 
This means that the lawful democratic state is not concerned principally with a delegation of authority from above, but rather with ensuring that the interests of the 'first-level' communities are 'both recognized and effectively brokered, so that none of these communities is threatened in its pursuit of the social good by others ${ }^{\prime 18}$ Because it is no longer an absolute, this means, according to this pluralist model, that

the lawful state embodies the possibility of its being held to account; it denies its own invulnerability from criticism. Its sovereignty is not a claim to be the source of law, but the agreed monopoly of legal force and a recognition of where the ultimate court of appeal is to be located for virtually all practical and routine purposes. ${ }^{19}$

The state thus exists in virtue of the free consent of the members of the 'first-level' organizations who have accorded to it the role of arbitration and balance. It will facilitate 'co-operation through its own sponsorship and partnership' ${ }^{20}$ In turn this leads on to a kind of subsidiarity but - and here it stands in contrast to the use of the word in most British political discourse - one in which the reference is always upwards rather than downwards. ${ }^{21}$

The role of the state in a complex society will thus be twofold: first, it will have an interest 'in securing the liberty of groups to pursue their own social goods', and second, it will have 'an interest in building into its own processes a set of cautions and defences against absolutism'. ${ }^{22}$ On the one hand, then, the lawful state ensures that basic human dignity is preserved and life is safeguarded, while, on the other hand, it 'embodies the possibility of its being held to account; it denies its own invulnerability from criticism'. This means that its 'sovereignty is not a claim to be the source of law, but the agreed monopoly of legal force and a recognition of where the ultimate court of appeal is to be located for virtually all practical and routine purposes' ${ }^{23}$ This means that the state will guard against what has been called 'repressive tolerance', that is, as Williams suggested (in a different context) 'an intellectually idle and morally frivolous prohibition against raising uncomfortable questions' about truth. Never, however, is the state the sole source of authority or truth or beyond criticism. ${ }^{24}$

18. 'Law, Power and Peace', p. 4.

19. 'Law, Power and Peace', p. 9.

20. 'Law, Power and Peace', pp. 7-8.

21. 'Law, Power and Peace', p. 5.

22. 'Law, Power and Peace', pp. 7-8.

23. 'Law, Power and Peace', pp. 8-9.

24. 'The Unity of Christian Truth', in On Christian Theology, pp. 16-28 (17). 
Within this pluralist system the role of the Church and the Christianity it represents is complex. Williams regards the political role of churches as principally that of deflating the claims of the state, of reminding it that its role is primarily that of negotiation or balance rather than sovereignty or command. He claims that no state can ever be accorded absolute authority for one simple reason:

the Christian tradition rests upon a strong conviction that no political order other than the Body of Christ can claim the authority of God; and the Body of Christ is not a political order on the same level as others, competing for control, but a community that signifies, that points to a possible healed human world. Thus its effect on the political communities of its environment is bound to be, sooner or later, sceptical and demystifying. ${ }^{25}$

The true sovereign is Christ and no other claims to authority can ever hope to compete. Indeed, Williams regards this as inherent in Christianity through history, even when it appeared most authoritarian. As he claimed in a recent lecture given in Liverpool on 'Europe, Faith and Culture':

Christianity might have been the system taken absolutely for granted by the society of Western mediaeval Europe, but it still contained the seeds of deep cultural unease, an irony and a scepticism about existing situations and systems in the light of God's action in the cross of Jesus and the revelation of what God's justice really meant. ${ }^{26}$

In the end, it was the cross that led to the sceptical tendency in all Christianity. This meant that the Christian should be 'wary of any such universal sovereignty as of any sacred claims for this or that national polity. There is, ultimately, only one sovereignty which is theologically grounded, and that is Christ's's. ${ }^{27}$ Consequently, according to Williams, there would always be an ambiguity in the relationship between church and state. It comes as no surprise then that he writes: 'Christianity has a mixed history of relation with political power. It has always been a complex balance'. ${ }^{28}$ It needs both to engage with power, but also to retain a sceptical distance. In this way it becomes a kind of critical friend or conversation partner with the state and its laws.

25. 'Law, Power and Peace', p. 9.

26. 'Europe, Faith and Culture', speech given at Liverpool, January 26, 2008. Posted at: http://www.archbishopofcanterbury.org/1547

27. 'Law, Power and Peace', p. 7.

28. Lecture given on May 12, 2007 at St Andrew's Cathedral, Singapore: 'Christianity: Public Religion and the Common Good'. Posted at: http:// www.archbishopofcanterbury.org/495 
Given his denial of absolutism and sovereignty, Williams has an ambiguous relationship with political liberalism. In particular, he is deeply suspicious of universalistic versions of liberalism, which suppose that the liberal state has the responsibility to dictate and define all forms of human identity in terms of a monolithic centrally imposed system. In his Chatham Lecture, for instance, he characterizes the problems of secularism:

\begin{abstract}
what we see, in the actual policies of some states and in the rhetoric of the political classes in other states, is a presumption that the rational secular state is menaced by the public or communal expression of religious loyalty. ... Conviction is free - that is a foundational principle of modern liberal society; but visible and corporate loyalty to the marks of such conviction ... puts in question the neutrality of the public space and can be read as a sort of aggression against other convictions or against the programmatic absence of convictions that the state assumes for public purposes. For statutory authority to collude with, let alone actively support these loyalties fatally compromises the very basis of legitimate liberal society. ${ }^{29}$
\end{abstract}

At the same time, however, Williams recognizes that the critical impulse behind 'interactive pluralism' also emerges from the questioning of authority, which has been the great triumph of the political liberalism that emerged in Europe in the Enlightenment, but which has its seeds much earlier in history. Indeed, he claims, what is best in liberalism is what is best in Christianity, since ultimately interactive pluralism is founded on Europe's Christian heritage. He consequently writes of the virtues of political liberalism that they 'will survive best if they are seen as the outgrowth of the historic European tensions about sovereignty, absolutism, and the integrity of local communities that were focused sharply by the Christian church and its theology - a theology that encouraged scepticism about any final political settlement within history'. ${ }^{30}$ An ironic detachment from all systems is thus at the heart of Christian political theology. This results in the 'readiness to question in the name of a something more that God alone opens up and makes possible'. Williams consequently suggests:

Christian faith tells us that, because God is to be trusted, we can be very bold indeed about the degree of scepticism we give to what is less than

29. 'Convictions, Loyalties and the Secular State', Chatham Lecture, October 29, 2004. Posted at: http://www.archbishopofcanterbury.org/1478. See also 'The Judgement of the World' in On Christian Theology, p. 35.

30. 'Religion, Culture, Diversity and Tolerance'. 
God. In the context of faith, this is the 'unbearable lightness' that is given us in relation to the systems and expectations of the world around, the irony that is still compatible with love and commitment in God's name. ${ }^{31}$

At the same time, the Christian faith in the equality and dignity of all human beings as created in the image of God helps guard against the loss of a conviction that there is a 'common hope and vocation for human beings, such that the welfare or salvation of one section of humanity cannot be imagined as wholly different from or irrelevant to that of the rest of the race'. ${ }^{32}$

According to Williams's understanding of theology, the political role of the Church is understood principally as that of calling the state to account by 'obstinately asking the state about its accountability and the justification of its priorities'. The liberal state is thus obliged to listen if it is not to turn secularism into 'another tyranny'. ${ }^{33}$ Here again Williams moves to a discussion of the role of the state as mediator and 'space-maker' rather than sovereign. The key role of the Church is to ensure that the state claims nothing more. If that is the case then the state will be primarily that place

\begin{abstract}
in which mediation and mutual listening will be normal. ... If religious communities are acknowledged as participants in public argument, they are bound to some level of creative engagement with each other and with the secular voice of the administration, so as to find a solution that has some claim to be just to a range of communal interests. ${ }^{34}$
\end{abstract}

The alternative, which is maintained by those who regard religious communities as little more than private arrangements between consenting adults, will lead to exclusion and ghettoization, even to what the Bishop of Rochester has recently and rather hysterically called 'no-go areas'. Nazir-Ali's solution amounts to a return to Christianity as the historic English public faith with little regard to pluralism or seeing other religions as 'first-level' communities of equivalent status. ${ }^{35}$

In distinction, Williams holds that what is key to human identity is not a vague sense of Britishness or Europeanism, but a solidarity that

31. 'Europe, Faith and Culture'.

32. 'The Unity of Christian Truth', p. 17.

33. 'Europe, Faith and Culture'.

34. 'Religion, Culture, Diversity and Tolerance'.

35. Michael Nazir-Ali, 'Extremism flourished as UK lost Christianity', Sunday Telegraph, January 11, 2008. 
emerges from the primary unit of socialization, which, for many, will be their religion. Thus he writes:

The faith community - like other self-regulating communities - has to be seen as a partner in the negotiations of public life; otherwise, the most important motivations for moral action in the public sphere will be obliged to conceal themselves; and religious identity, pursued and cultivated behind locked doors, can be distorted by its lack of access to the air and the criticism of public debate. ${ }^{36}$

Interactive pluralism thus becomes a way to ensure participation in the political process by respecting other cultures and religions as agents of identity, and drawing them into a wider debate negotiated cautiously by the institutions of the state, most obviously the democratic process itself, at the local, national, and international level. As Williams put it in his Chatham lecture:

Loyalty to a sovereign authority is replaced by or recast as identification with a public process or set of public processes; the simple question about loyalty, 'Are you with us or against us?' becomes a question about adequate and confident participation in a law-governed social complex. ${ }^{37}$

In this way, European politics will mature into what Williams calls 'effective partnership with the component communities of the state, including religious bodies'. European politics, he claims, will thus

try to avoid creating ghettoes. It will value and acknowledge all those sources of healthy corporate identity and political formation (in the widest sense) that are around. ... By holding the space for public moral argument to be possible and legitimate, it reduces the risk of open social conflict, because it is not content to relegate the moral and the spiritual to a private sphere where they may be distorted into fanaticism and exclusion. For Europe to celebrate its Christian heritage in this sense is precisely for it to affirm a legacy and a possibility of truly constructive pluralism. ... And for the Church to offer this to Europe (and from Europe to the wider world) is not for it to replace its theology with a vague set of nostrums about democracy and tolerance but for it to affirm its faithfulness to the tradition of Christian freedom in the face of the world's sovereignties. ${ }^{38}$

Williams's recent Royal Courts Lecture, ${ }^{39}$ which provoked much ill-informed criticism, is a further example of 'interactive pluralism',

36. 'Law, Power and Peace', p. 4.

37. 'Convictions, Loyalties and the Secular State'.

38. 'Religion, Culture, Diversity and Tolerance'.

39. 'Civil and Religious Law in England: a Religious Perspective', Royal Courts of Justice, February 7, 2008. Text at: http://www.archbishopofcanterbury.org/1575 
which Williams explains (in a different context) as 'a situation in which difference is publicly acknowledged and given space, but not regarded as an excuse for "ghettoization" or exclusion from a serious degree of shared work, shared resources and mutual responsibility'. ${ }^{40}$ Interactive pluralism is consequently hard work and requires constant testing. As will be shown in the next section, it is in this broader context that the lecture needs to be understood.

\section{Islam}

The Royal Courts Lecture was an intelligent and wide-ranging discussion of some of the key issues involved in the reciprocal relationships between religious communities and the wider society. It touched on the themes of sovereignty, particularly as expressed through law. Williams's primary aim was to ensure that dialogue with Islam is maintained as the pluralist state negotiates space for all religious groups. As it does this, however, it needs to protect freedom, while at the same time fostering minority religious participation in the political process. However, although he was specifically addressing Islam, the lecture has implications for any faith group, including the churches. In contemporary Britain all such groups are 'first-level associations', and as such, and like the other constituent groups that make up society, all are voluntary organizations. In modern Europe all religious communities are minority communities. This means that they are forced to co-exist, but also to engage with one another within certain limits that are circumscribed and negotiated by the state. At the same time, however, 'first-level' associations are public and political rather than private societies. They provide a primary - sometimes the only source of socialization and identity.

Despite the nostalgic attachment to establishment by some, and the implausible designation of a Christian Europe by others, Williams holds that in practice all religions will need to address these issues. ${ }^{41}$ This makes criticism from within the church at the very least disingenuous, since all religious people are in practice in much the same boat. In an ill-judged article in the Sunday Telegraph, ${ }^{42}$ for instance, George Carey concludes with an aside that, since Muslims constitute a mere three per cent of the population, the proposals set out by

40. Presidential address to November 2005 synod.

41. See 'The Judgement of the World', p. 35.

42. George Carey, 'Are we promoting harmony or Muslim ghettoes?', in The Sunday Telegraph, February 10, 2008. 
Williams would be like using a 'sledgehammer to crack a nut'. What he fails to observe, however, is that this percentage is higher than the number of practising Anglicans. Williams's question is thus vital for all religions. He consequently asks as to 'what degree of accommodation the law of the land can and should give to minority communities with their own strongly entrenched legal and moral codes'. On his model of interactive pluralism it affects Christians as well as members of the minority faiths, since Christians too are inevitably a 'minority community'. ${ }^{43}$ As Williams wrote earlier in his Chatham lecture:

the Church as a political agent has to be a community capable of telling its own story and its own stories, visible as a social body and thus making claims upon human loyalty. While not a simple rival to the secular state, it will inevitably raise questions about how the secular state thinks of loyalty and indeed of social unity or cohesion. To this degree, it is not in a different case from the Muslim Umma. ${ }^{44}$

In the complex society of modern Britain the answers cannot be straightforward. In particular, any discussion of Islam is especially sensitive, as is demonstrated by the hysteria that greeted the lecture. However, the lecture fits into Williams's overall political framework. While complex, his central argument is clear. First, drawing on recent scholarship, he shows that sharia law is not a monolithic system but is always related to context. This means that there does not have to be a 'standoff between two rival legal systems when we discuss Islamic and British law'. Secondly, wherever there is a recognition that Islam co-exists alongside other faiths (and none), then any acceptance of sharia law will need to be a free choice on the part of those belonging to the Islamic community (and the same would hold true for members of other religions in choosing their own laws). Drawing on the writings of Tariq Ramadan, Williams had earlier made this point in his lecture on 'Religion, Culture, Diversity and Tolerance':

There is, says Ramadan, no single 'homeland' for Muslims: they can be at home in any geographical and political environment, and they need to avoid 'self-ghettoisation', becoming 'spectators in a society where they were once marginalized'. They need to be arguing and negotiating in the public sphere.

Ramadan even suggests that Islam shares a similar critique of the state to Christianity. He writes: 'the Muslim distinction between

43. 'Civil and Religious Law in England'.

44. 'Convictions, Loyalties and the Secular State'. 
religious and social authority, between what is enjoined for the good of the soul and what is ordered for the stability of an external environment, is really much the same as the Christian distinction between church and state'. Islam is not restricted to primitive and fundamentalist forms. Instead, Williams claims:

Commitment to the lawfulness of the processes of argument in a society and acceptance of the outcome of ordered negotiation is presupposed by the political ethics of both traditions. Without that, we should simply revert to the ghetto ethics from which Ramadan is seeking to liberate his co-religionists. ${ }^{45}$

For this reason a Muslim (as well as the practitioner of any other religion) will have a dual or multiple (sometimes called a 'hybrid') identity. This means that there will inevitably be a degree of 'political plurality' where our 'social identities are not constituted by one exclusive set of relations or mode of belonging'. ${ }^{46}$

For Williams, there are two related dangers that might emerge if this dialogue with Islam is not attempted: on the one hand, failure to engage might lead to the growth of those religious groups who see any participation in the political process as a kind of betrayal, while, on the other hand, it might strengthen those who regard the secular government as solely responsible for the construction of public identity. Understanding the complex relationships between religious groups and legal and state authority is thus crucial. For this reason the law of the land needs to be clear about precisely what counts as a matter of religious conscience, which brings with it important issues concerning the social and economic status of minority communities and their access to the political process.

This leads Williams on to the problem first, of the place of 'religious scruple' in legal cases, which requires a sensitivity to the religious and cultural 'construction of people's identities'. It becomes imperative that there is some way of distinguishing between cultural habits and 'seriously rooted matters of faith and discipline'. If there were to be more latitude given to 'rights and scruples rooted in religious identity' there would also need to be an enhanced Muslim legal council to interpret and decide in such matters. Secondly, and more controversially, Williams moves on to discuss the area of 'supplementary jurisdiction' and its relationship with the universal law of the land. He is clear that there needs to be a way of safeguarding it from simply 'reinforcing in minority

45. Citing Tariq Ramadan, Western Muslims and the Future of Islam (Oxford: Oxford University Press, 2004), pp. 53, 55.

46. 'Religion, Culture, Diversity and Tolerance'. 
communities some of the most repressive and retrograde elements in them'. In a plural society there can be no question of taking away rights that are acknowledged as universally valid, or deny the citizen access to the law. Recognizing a supplementary jurisdiction, he writes, 'cannot mean recognizing a liberty to exert a sort of local monopoly in some areas'. Political plurality consequently means that citizenship will consist of a complex set of identities. Quoting a Jewish legal theorist, he suggests that we need to "work to overcome the ultimatum of "either your culture or your rights"'.

Williams's third problem concerns the commitment to legal monopoly, which is firmly established in European legal systems. While this is central to issues of protection and equality of access to the law, at the same time it fails adequately to grasp the complexities of 'multiple affiliation' ${ }^{47}$ The key point here is the confusion that arises from seeing law as a protection for the citizen as somehow implying that the sovereign state authority has the responsibility for permitting all other levels of identity to exist. Religion would then be a secondary association, or even a purely private matter. Politically this is dangerous principally because it leads to a ghettoized form of social life religion, which is far more than a set of private beliefs and which is key to human identity, would nevertheless be lived out behind closed doors and beyond the reach of the law. In the pluralist state, according to Williams, law should protect all citizens and consequently monitor the rules and activities which members of religious communities use to regulate their affairs - this is a crucial point in that it prevents the creation of 'mutually isolated communities' where individuals are constrained purely by their communities and traditions and where there can be no public redress. Law consequently functions as a kind of regulatory framework, 'a way of honouring what in the human constitution is not captured by any one form of corporate belonging or any particular history'. Put simply, in a pluralist context religion is not a private activity but is a complex political identity that lives in an uneasy symbiotic relationship with the wider society.

47. In his ill-judged criticism in The News of the World (February 10, 2008) George Carey writes: '[Williams'] conclusion that Britain will have to concede some place in law for aspects of Sharia is a view I cannot share'. But when he claims that ' $\mathrm{t}$ ] here can be no exceptions to the laws of our land which have been so painfully honed by the struggle for democracy and human rights', one wonders how he would feel if the Church of England were suddenly forced to accept equal rights legislation in relation to practising homosexuals who might be called to the episcopate. 
This leads Williams to some tentative conclusions: the essentially liberating vision of universal human rights, he claims, is not imperilled by a loosening of its monopolistic framework. Instead in complex plural societies there is a need for 'transformative accommodation' where in carefully circumscribed matters 'power-holders are forced to compete for the loyalty of their shared constituents'. This system will be complex and fraught with difficulties. But an over-rigid application of a monopolistic framework is worse. It can have the effect of 'ghettoizing and effectively disenfranchising a minority: both jurisdictional parties may be changed by their encounter over time, and we avoid the sterility of mutually exclusive monopolies'. While many secularists find it hard to defend faith schools, Williams suggests that they 'bring communal loyalties into direct relation with the wider society and inevitably lead to mutual questioning and sometimes mutual influence towards change, without compromising the distinctiveness of the essential elements of those communal loyalties'. ${ }^{48}$ Elsewhere he writes:

To pick up a currently controversial issue, the state's assistance to 'faith schools' is not the subsidising of exclusivism but the bringing of communities out of isolation to engage with the process of maintaining what they and other communities together need, and to argue and negotiate. The state is thus more than a tribunal; it exercises its lawful character by promoting and resourcing collaboration. ${ }^{49}$

\section{Conclusion}

What I hope I have shown in this discussion is that Williams's longterm project of interactive pluralism is a coherent if controversial approach to politics, which is directly related to multiculturalism and the state's relationship to minority religious communities, which includes the Christian churches. It is rooted in a theological understanding of sovereignty as well as in the equality of all people as created in the image of God. At the same time it draws on a relatively neglected tradition of English political thought which reached its heyday in Edwardian England, but which declined rapidly after the First World War. ${ }^{50}$ Interactive pluralism rests on several basic

48. 'Civil and Religious Law in England'.

49. 'Law, Power and Peace', p. 8.

50. Matthew Grimley, Citizenship, Community, and the Church of England: Liberal Anglican Theories of the State Between the Wars (Oxford: Clarendon Press, 2004), ch. 2, pp. 65-102. 
assumptions: first, religion is not a private matter but, even though it is voluntary, it is nevertheless a 'first-level' association, which is central for the political and social identity of its adherents. Secondly, although religious adherents will also share other identities, one of which is likely to be national citizenship, the state itself cannot function as a 'first-level' association, at least for religious people. This would be to impose a kind of national and state-directed pseudoreligious homogeneity, which would be to overstep the limited nature of sovereignty. Instead the state confers space, protects the vulnerable, and encourages dialogue, without determining the content and character of that dialogue, nor the precise details of the teachings of the 'first-level associations'. ${ }^{51}$

According to Williams, religions and other social groups do not occupy a 'neutral' and private space, but instead they are political associations. This differentiates him from those liberal multiculturalists who have been criticized by Trevor Phillips who - in words reminiscent of the Bishop of Rochester - spoke of 'marooned communities', which would 'steadily drift away from the rest of us' into 'crime, no-go areas and chronic conflict'. ${ }^{52}$ But Williams does not resort to the wishful thinking of those such as Ian Bradley who would create an imaginary community of belonging or a new multi-faith conception of Britishness. ${ }^{53}$ Instead, on the basis of his pluralism, Williams identifies a common core of national identity in little more than agreeing to abide by a minimum set of rules for negotiation provided by the space-making state.

The political philosopher, Chandran Kukathas, has called this sort of model the 'liberal archipelago', or 'a society of societies which is neither the creation nor the object of control of any single authority, though it is a form of order in which authorities function under laws which are themselves beyond the reach of any singular power' (and which consequently have to be settled by negotiation). ${ }^{54}$ Under this model the state is 'no more than a transitory political settlement whose

51. I attempted something similar in my Blair's Britain: A Christian Critique (London: DLT, 2005), especially ch. 7, pp. 83-100.

52. Trevor Phillips, 'After 7/7: Sleepwalking to Segregation' (Speech given at Manchester Town Hall, September 22, 2005) at: http://www.cre.gov.uk/Default. aspx.LocID-0hgnew07r.RefLocID-0hg00900c001001.Lang-EN.htm

53. Ian Bradley, Believing in Britain (London: I.B. Tauris, 2007), especially ch. 6, pp. 167-200.

54. Chandran Kukathas, The Liberal Archipelago: A Theory of Diversity and Freedom (Oxford: Oxford University Press, 2003), pp. 8-9. 
virtue is that it secures civility' ${ }^{55}$ It will have little interest in 'cultural integration' or 'cultural engineering', but will be concerned first and foremost with the freedom of association, that is, with providing the conditions for the existence of 'basic-level' free associations. Although Williams would probably not go as far as Kukathas, there is nevertheless something important in the claim that 'a liberal society will be one in which politics is given priority over morality'. ${ }^{56}$ In such a society the 'state would be a much diminished entity, a good deal less capable of establishing and imposing common standards for the nation' ${ }^{57}$ Morality, we might add, will be developed in the process of negotiation between living communities.

In order that this sort of minimal state might flourish, Williams recognizes the need for a participatory form of democracy to ensure that members of the different first-level associations are able to accept the rights and place of other groups, that is, to accept the shared space for negotiation. If this does not happen - which is highly probable when religion is treated simply as private and personal the likelihood is that ghettoization will result and there will be little interest in the political process (and little engagement with other 'first-level' associations). For Williams, multiculturalism is thus not about fragmentary and competing private goods and the resulting separatism between communities, ${ }^{58}$ but instead is about negotiation between different and sometimes competing public truths. This negotiation takes place, however, within the limits of certain agreed rules maintained by the law and institutions of the state. Here there is some continuity between Williams and what Anthony Giddens calls 'sophisticated multiculturalism', ${ }^{59}$ as espoused for instance by Charles Taylor who stresses the need for mutual recognition and respect between communities within a 'community of fate', that is, the national community with few metaphysical claims. ${ }^{60}$ What is different for Williams, however, is the priority that he gives to 'first-level associations' rather than to the 'community of fate' (which can sometimes become contorted into a bizarre fixation on 'being British'). Although much recent Government thinking has focused on community cohesion, on helping

55. Kukathas, The Liberal Archipelago, p. 15 (cf. p. 19).

56. Kukathas, The Liberal Archipelago, p. 19.

57. Kukathas, The Liberal Archipelago, p. 31.

58. Tariq Modood, Multiculturalism: A Civic Idea (Cambridge: Polity, 2007).

59. Anthony Giddens, Over to You, Mr. Brown (Cambridge: Polity, 2007), p. 155.

60. See Charles Taylor, Multiculturalism: Examining the Politics of Recognition (Princeton: Princeton University Press, 1994). 
groups to negotiate and communicate with one another, there has been rather less emphasis on developing a political system where negotiation can be promoted without some sort of externally imposed identity (Islam, Asian) as a substitute for a voluntary community of association (which may be multiple and hybrid). For this to happen in the British context there would need to be major constitutional changes that would move to decentralization.

Despite community cohesion policies, however, participation in the political process, especially at local levels, has sunk to an all-time low - and that might be because people identify not primarily with the monopolistic legalistic state (with Britain or Britishness or even England, Wales or Scotland) but with a range of different groups, the most important of which for religious people will be their faith. Since identity is primarily a local business, this means that policies of local enfranchisement and 'inclusion' might be the best starting blocks for the development of a politics of interactive pluralism. In his Chatham lecture, Williams makes some tentative suggestions for how this might affect public policy. Drawing on the work of the Muslim legal theorist, Maleiha Malik, he claims that there

needs to be a pathway for minority communities to find new ways of identifying with public processes and social institutions, so that (instead of making the main form of protection against discrimination the guarantees provided by the courts, and so consuming immense energy in litigation) specific groups may play a positive role in framing policy before legislation is finalised. And this needs more developed representative institutions of consultation. The issue of 'rights' for a minority religious community thus comes to be allied with a wider set of questions about local democracy and the weaknesses of an 'elective dictatorship' model of parliamentary rule. ${ }^{61}$

Interactive pluralism might well be the best way forward for a healthy democratic state. Politics becomes a negotiation between groups, and in turn the state and its legal system becomes an arbitrator, which favours no one group but which encourages all to contribute and to participate. While there may be questions about the ultimate role of the state, especially in an emergency when decisions

61. 'Convictions, Loyalties and the Secular State'. Citing Maleiha Malik, 'Muslims and Participatory Democracy', in Mohammad Siddique Seddon, Dilwar Hussain and Nadeem Malik (eds.), British Muslims: Loyalty and Belonging (London: Citizen Organising Foundation, 2003), pp. 69-85: 'Institutional identification is more likely where substantive issues concerning the common good are discussed' (p. 80). 
simply have to be made, the challenge to absolutism offered by Williams's thought offers a very different picture of the state from that maintained for so long, especially in the history of England. Although this may be too much for many to bear, especially those who long romantically for the harmony of the Christian state, it seems to me to be central for the survival of democracy - and it is far better to learn to live with reality than to cling on to some imaginary past (or, which is even worse, to accept the secularist privatization of religion). Williams writes:

ultimately we do not have to be bound by the mythology of purely private conviction and public neutrality; and, if my general argument is right, the future of religious communities in modern society should show us some ways forward that do not deliver us either into theocracy or into an entirely naked public space. ${ }^{62}$

At the very least interactive pluralism seems a model for political participation that avoids these errors, and for that reason alone it is worth trying. It might also help religions overcome their mutual distrust, suspicion and prejudice. But that requires a humility, which only some are able to tolerate.

62. 'Convictions, Loyalties and the Secular State'. See 'The Judgement of the World', p. 37. 